J. Reprod. Fert. (1973) 34, 93-104

\title{
ANDROGEN BIOSYNTHESIS BY TESTICULAR TISSUE OF THE DESERT RODENTS, ACOMYS CAHIRINUS AND GERBILLUS DASYURUS
}

\author{
E. BEDRAK, V. SAMOILOFF AND M. SHACHAK* \\ Division of Life Sciences, Negev Institute for Arid Zone Research, \\ Beer Sheva, and *Ecological Research Unit, Midrashat Sdeh-Boker, Israel
}

(Received 5th Fuly 1972)

\begin{abstract}
Summary. Androgen biosynthesis was investigated in the desert rodents, Acomys cahirinus and Gerbillus dasyurus. In these experiments, radioactive substrates were incubated with testicular homogenates and the metabolites formed were identified. The accumulation of 5 -ene-3 $\beta$ hydroxysteroids suggested that the biosynthesis proceeded preferentially by the 4-ene route. This was confirmed by double-label experiments where $\left[{ }^{3} \mathrm{H}\right] 5$-ene- $3 \beta$-hydroxysteroids and $\left[{ }^{14} \mathrm{C}\right] 4$-en-3-oxosteroids were employed. The preferred route for the production of the major androgens appears to be pregnenolone $\rightarrow$ progesterone $\rightarrow 17 \alpha$-hydroxyprogesterone $\rightarrow$ androstenedione $\rightarrow$ testosterone. In addition, these species were characterized by enhanced activity of $20 \alpha$-hydroxysteroid oxidoreductase and low activity of $17 \beta$-hydroxysteroid oxidoreductase, a phenomenon also observed in the laboratory rat and mouse acclimatized to a hot environment. Some parameters of desert ecology are briefly described.
\end{abstract}

\section{INTRODUCTION}

With the increasing shortage of existing arable land, deserts and arid zones have to be made more habitable for man. In an attempt to discover how the natural animal populations of these areas survive in their inhospitable environment, we have studied two of the most common desert rodents, Acomys cahirinus and Gerbillus dasyurus. These two mammals are widely distributed, $A$. cahirinus being found in India, South Persia, South Saudi Arabia, Israel, Cyprus, Crete, Egypt, Libya, Algeria, East Africa and Rhodesia, and G. dasyurus in Western India, Iraq, Saudia Arabia, Israel, Egypt, Libya, Algeria, Somalia, Sudan and Kenya (Ellerman \& Morrison-Scott, 1966).

The animals used were trapped in the Negev Desert where they live amongst ridges of sedimentary rocks in an environment of sharply fluctuating daily and seasonal temperatures. Both types of rodents shelter in underground burrows, but the more dominant $A$. cahirinus lives on the hill slopes while $G$. dasyurus is driven off to the less comfortable hill-top burrows. Through its long relegation to a harsher environment, $G$. dasyurus has become more resistant to adverse conditions and maintains a more efficient water balance. Both $A$. cahirinus and 
G. dasyurus are nocturnal species, and are active at ground surface level only after sunset when the temperature has fallen.

Numerous investigators have determined the details of androgen biosynthesis in various mammalian species and the information has been summarized (Eik-Nes, 1970), but less information is available on desert rodents (Bedrak, Samoiloff \& Finkelstein, 1971). An awareness of the reactions participating in androgen biosynthesis in desert rodents would indicate the trend of change in enzymatic activity that might be anticipated upon acclimatization of mammals to an elevated ambient temperature. This information would be particularly important in the introduction of mammals to desert areas where the day temperature often exceeds the scrotal temperature-an important factor in relation to testicular function.

The experiments described here show that, in the adult males of $A$. cahirinus and $G$. dasyurus, testosterone is synthesized from progesterone $\rightarrow 17 \alpha$-hydroxyprogesterone $\rightarrow$ androstenedione $\rightarrow$ testosterone (4-ene-pathway) as well as from pregnenolone $\rightarrow 17 \alpha$-hydroxypregnenolone $\rightarrow$ dehydroepiandrosterone $\rightarrow 5$-androstene-3 $\beta, 17 \beta$-diol $\rightarrow$ testosterone (5-ene-pathway), but the enzymes of the first pathway are more active, suggesting that testosterone is primarily synthesized by the 4-ene-route. The following trivial and systematic names are used: pregnenolone, $3 \beta$-hydroxy-5-pregnen-20-one; progesterone, 4-pregnene-3,20dione; $17 \alpha$-hydroxyprogesterone, $17 \alpha$-hydroxy-4-pregnen-3,20-dione; $17 \alpha$-hydroxypregnenolone, $3 \beta, 17 \alpha$-dihydroxy-5-pregnen-20-one; $17 \alpha, 20 \alpha$-dihydroxyprogesterone, 17 $\alpha, 20 \alpha$-dihydroxy-4-pregnen-3-one; dehydroepiandrosterone (DHA), 3 $\beta$-hydroxy-5-androstene-17-one; androstenediol, 5-androstene-3 $\beta$, $17 \beta$-diol; androstenedione, 4-androstene-3,17-dione; and testosterone, $17 \beta$ hydroxy-4-androstene-3-one.

Animals

\section{MATERIALS AND METHODS}

Specimens of G. dasyurus and A. cahirinus were trapped in the Negev desert area. Mice (C57-B1/6) and rats were obtained from colonies raised in the Weizmann Institute, Rehovoth, and hamsters from the Hebrew University, Jerusalem. The laboratory animals were acclimatized to a hot environment by being kept at $35^{\circ} \mathrm{C}$ for 4 weeks (Bedrak, Samoiloff, Sod-Moriah \& Goldberg, 1971).

\section{Preparation of testicular homogenate}

All animals were killed by cervical dislocation. The testes were removed immediately, stripped of their capsules and dropped into ice-cold $0.25 \mathrm{M}$ sucrose solution. Groups of three to five pairs of testes were blotted on filter paper and weighed. A homogenate $(1: 10, \mathrm{w} / \mathrm{v})$ was prepared in $0.25 \mathrm{M}$-sucrose containing $0.001 \mathrm{~m}$-EDTA. The homogenate was centrifuged for $15 \mathrm{~min}$ at $800 \mathrm{~g}$ to remove nuclei and connective tissue, and the supernatant was then used for incubation.

\section{Radioactive steroids}

Radioactive steroids (The Radiochemical Centre, Amersham, England) 
were purified before incubation by paper chromatography in the hexaneformamide system (Zaffaroni, 1953). They were diluted with inert material, ${ }^{14} \mathrm{C}$-labelled compounds to a specific activity of 2.5 to $7.5 \mu \mathrm{Ci} / \mu \mathrm{mol}$, and ${ }^{3} \mathrm{H}$ labelled compounds to a specific activity of 25 to $37.5 \mu \mathrm{Ci} / \mu \mathrm{mol}$.

\section{Incubation, chromatography and identification of steroids}

Incubations were carried out in duplicate in a total vol. of $1.0 \mathrm{ml}$. The buffer and cofactors employed in the incubation media and the extraction techniques have been described by Bedrak, Samoiloff \& Finkelstein (1971). The extracts were chromatographed and metabolites were detected on the chromatograms as described by Bedrak \& Samuels (1969). The areas containing a mixture of steroids, i.e. pregnenolone and progesterone, androstenedione and DHA, $17 \alpha-$ hydroxyprogesterone and testosterone, $17 \alpha$-hydroxypregnenolone and 5-androstene $3 \beta, 17 \beta$-diol, were acetylated according to Dominguez, Seely \& Gorski

Table 1. Recrystallization of steroids to constant specific activity

\begin{tabular}{|c|c|c|c|c|c|}
\hline \multirow{2}{*}{ Steroid } & \multirow{2}{*}{$\begin{array}{l}\text { Original } \\
\text { solution }\end{array}$} & \multicolumn{4}{|c|}{ No. of recrystallizations } \\
\hline & & First & Second & Third & Fourth \\
\hline $\begin{array}{l}\text { Pregnenolone acetate } \\
\text { Progesterone } \\
\text { 17 } \alpha \text {-hydroxypregnenolone } 3 \text {-acetate } \\
\text { 17 } \alpha \text {-hydroxyprogesterone } \\
17 \alpha, 20 \alpha \text {-dihydroxy-4-pregnen-3-one } \\
\text { Androstenedione } \\
\text { Dehydroepiandrosterone acetate } \\
\text { Testosterone acetate } \\
5 \text {-androstene- } 3 \beta, 17 \beta \text {-diol }\end{array}$ & $\begin{array}{r}570 \\
1335 \\
1540 \\
1600 \\
1210 \\
350 \\
1065 \\
475 \\
335\end{array}$ & $\begin{array}{r}530 \\
1340 \\
1505 \\
1920 \\
1230 \\
335 \\
1010 \\
420 \\
240\end{array}$ & $\begin{array}{r}545 \\
1310 \\
1560 \\
1940 \\
1130 \\
345 \\
1030 \\
405 \\
245\end{array}$ & $\begin{array}{r}535 \\
1315 \\
1550 \\
1780 \\
1100 \\
340 \\
1040 \\
430 \\
245\end{array}$ & $\begin{array}{r}535 \\
1315 \\
1555 \\
1795 \\
1130 \\
345 \\
1025 \\
420 \\
250\end{array}$ \\
\hline
\end{tabular}

Values expressed in $\mathrm{d} / \mathrm{min} / \mathrm{mg}$.

(1963) and the metabolites were then separated by chromatography. Recovery throughout the purification procedure was over $80 \%$. The area of $17 \alpha, 20 \alpha-$ dihydroxy-4-pregnen-3-one was freed from any companions by chromatography in hexane: benzene $(1: 1)$ /formamide with overrunning $(6 \mathrm{hr})$. The final criterion of identification was recrystallization to constant specific activity. Representative results are summarized in Table 1 . The molar ratios of metabolites derived from 4-ene and 5-ene precursors were based on values obtained from recrystallization to constant specific activity. Protein was determined by the method of Lowry, Rosebrough, Farr \& Randall (1951). The activity of $17 \beta$-hydroxysteroid oxidoreductase was estimated from the conversion of $\left[4-{ }^{14} \mathrm{C}\right]$ androstenedione (in the presence of an NADPH-generating system) to $\left[4-{ }^{14} \mathrm{C}\right]$ testosterone, and reported as nmol product formed per mg protein of testicular homogenate per hr.

\section{Desert environment}

\section{RESULTS}

Sharp fluctuation in daily and seasonal temperature is observed in the area where the rodents were trapped. The maximum and minimum mid-summer 
(June) temperatures were $40^{\circ} \mathrm{C}$ and $12^{\circ} \mathrm{C}$ and those for mid-winter (January) were $26^{\circ} \mathrm{C}$ and $1.7^{\circ} \mathrm{C}$. Soil surface temperatures can drop to $-3^{\circ} \mathrm{C}$ in winter and may reach $70^{\circ} \mathrm{C}$ in summer. Relative humidity is low, averaging about $48 \%$ throughout the year; it is usually between 67 and $73 \%$ during the winter months, whereas mid-day summer values are in the 20 to $30 \%$ range. Sharp falls in nocturnal temperatures result in a heavy dew formation of about $25 \mathrm{~mm}$ water on 150 to 250 nights/year. This particular desert terrain has an average annual rainfall of $82 \cdot 4 \pm 40 \cdot 0 \mathrm{~mm}$.

Two types of burrows predominate: those near the hill tops and others on the hill slopes (Shachak \& McPhee, 1971). Conditions in the former were more extreme with sharp differences between day and night temperatures measured 50 to $100 \mathrm{~cm}$ inside, whereas in the slope burrows, the nychthemeral range was much narrower and these burrows were more effective in dispersing daytime extreme radiation load. More $G$. dasyurus were found in the area of warmer hilltop burrows than $A$. cahirinus which occupied the area of the cooler slope burrows.

\section{Physiology of the desert rodents}

In their natural habitat, these rodents breed in the spring (February to April). Once deprived of its freedom, $G$. dasyurus stops breeding completely, whereas $A$. cahirinus adapts to captivity and breeds throughout the year. Body weights of A. cahirinus females trapped during the breeding season ranged between $36 \cdot 8$ and $53.6 \mathrm{~g}$; body temperature (approximately 1 to $2 \mathrm{~cm}$ inside the rectum) varied between 33.2 and $40.2^{\circ} \mathrm{C}$ with extremely large variations between animals. Body weights of sexually mature males trapped during the breeding season were $48.9 \pm 2.01$ and $26.0 \pm 1.87 \mathrm{~g}$ for $A$. cahirinus and $G$. dasyurus, respectively.

\section{Metabolism of $C-21$ and $C-19$ steroids by $\mathrm{A}$. cahirinus testicular homogenate}

Table 2 presents experiments where a series of 4-en-3-oxosteroids and 5-ene$3 \beta$-hydroxysteroids were metabolized by $A$. cahirinus testicular homogenate in the presence of appropriate cofactors. After $120 \mathrm{~min}$ of incubation, $2.8 \%$ of progesterone was metabolized to testosterone, $6.5 \%$ to androstenedione and $9.6 \%$ to $17 \alpha, 20 \alpha$-dihydroxy-4-pregnen-3-one. Similarly, $20.4 \%$ of $17 \alpha$-hydroxyprogesterone was converted to $17 \alpha, 20 \alpha$-dihydroxy-4-pregnen-3-one, $14.3 \%$ to androstenedione and $2.5 \%$ to testosterone. The androgens (testosterone plus androstenedione) and 17 $20 \alpha$-dihydroxy-4-pregnen-3-one produced from these substrates were proportionately similar, thus suggesting that the activity of 17,20 -lyase was similar to that of $20 \alpha$-hydroxysteroid oxidoreductase. Androstenedione yielded $15.8 \%$ testosterone after $120 \mathrm{~min}$ of incubation, indicating a relatively low activity of $17 \beta$-hydroxysteroid oxidoreductase.

In contrast to progesterone, pregnenolone was metabolized rapidly within 60 min to form intermediary metabolites of both 5-ene-3-hydroxy and 4-en-oxo configurations. In addition, three unidentified metabolites were isolated which accounted for $19.5 \%$ of the substrate. Judging from their $R_{\mathrm{F}}$ values on different chromatographic systems, these metabolites could be identified with deoxycorticosterone, 11-dehydrocorticosterone and corticosterone. Since we were only 


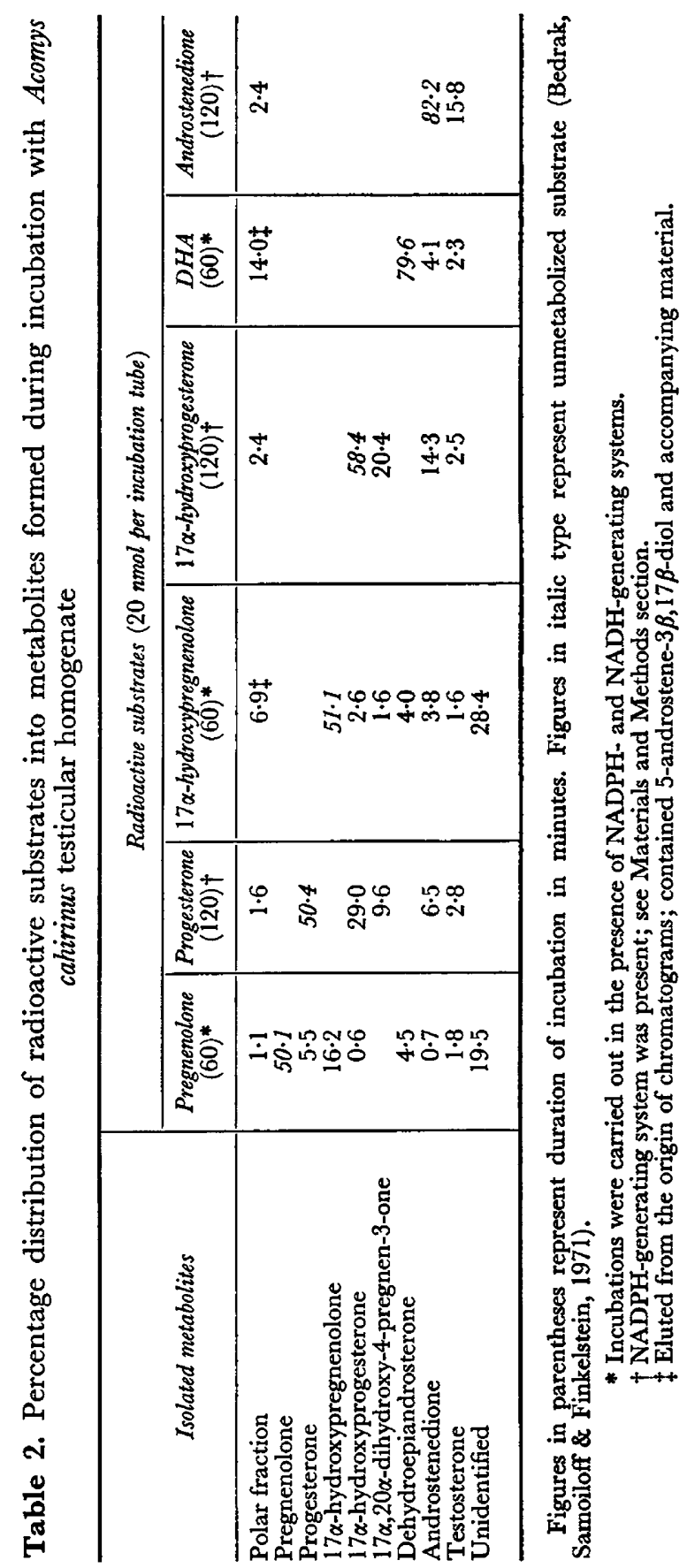


interested in the main metabolites associated with androgen production, these compounds were not identified further. The yields of $17 \alpha$-hydroxypregnenolone and DHA were $16.2 \%$ and $4.5 \%$; those of progesterone, $17 \alpha$-hydroxyprogesterone, androstenedione and testosterone were $5.5,0.6,0.7$ and $1.8 \%$, respectively. The high levels of 5 -ene- $3 \beta$-hydroxysteroids could mean either that they were the main metabolites, or that they were metabolized at a slower rate than the 4-en-3-oxosteroids. The compounds $17 \alpha$-hydroxyprogesterone, androstenedione and testosterone were probably synthesized by both the 5-ene and 4-ene routes, but the relative proportions contributed by either biosynthetic pathway could not be determined from these data. The metabolism of $17 \alpha-$ hydroxypregnenolone was similar to that of pregnenolone except for the higher yield of polar metabolites. The latter consisted of androstenediol and two unidentified accompanying metabolites. Upon incubation of dehydroepiandrosterone, both androstenedione and testosterone were formed at relatively low yields. The main products were androstenediol and two unidentified polar accompanying metabolites.

Metabolism of $C-21$ and $C-19$ steroids by homogenates made from testes of $\mathrm{G}$. dasyurus in the presence of $\mathcal{N} A D P H$

Incubation of $17 \alpha$-hydroxypregnenolone resulted in the formation of both 5 -ene and 4-ene metabolites (Table 3). The largest proportion was transformed to $17 \alpha, 20 \alpha$-dihydroxy-4-pregnen-3-one $(16.3 \%)$, followed by $17 \alpha$-hydroxyprogesterone $(9.9 \%)$, androstenedione $(3.2 \%)$, DHA $(1.3 \%)$ and testosterone $(0.6 \%)$. The polar fraction contained a mixture of steroids which on further chromatography corresponded to $17 \alpha, 20 \alpha$-dihydroxy-4-pregnen-3-one and androstenediol as well as two other unidentified polar compounds. As in the case of $A$. cahirinus, incubation of $17 \alpha$-hydroxyprogesterone resulted in a significant accumulation of $17 \alpha, 20 \alpha$-dihydroxy-4-pregnen-3-one $(26.5 \%)$ and a much smaller amount of androstenedione $(3.9 \%)$ and testosterone $(2 \cdot 1 \%)$.

Incubation of C-19 steroids was, with some variation, similar to that observed in A. cahirinus. Dehydroepiandrosterone was metabolized to testosterone $(14.2 \%)$, androstenedione $(11.1 \%)$ and a polar fraction (12.9\%) which contained, amongst others, some androstenediol. As expected, testosterone $(16.2 \%)$ was the only metabolite formed from androstenedione, and vice versa, androstenedione $(12.4 \%)$ was the only steroid formed when testosterone was incubated, in the presence of NADP, with testicular homogenates. Testosterone remained unmetabolized when NADPH was the added cofactor, implying that the 19hydroxylating and aromatizing enzyme systems are not active enough to be detected by the techniques used in the present experimental procedure.

Activity of 17 1 -hydroxysteroid oxidoreductase in testes of A. cahirinus, G. dasyurus, and control and heat-acclimatized laboratory rodents

The low conversion of various precursors to testosterone suggests that one or more of the key-enzymes in androgen biosynthesis may have lower activity in $A$. cahirinus and $G$. dasyurus than in the common laboratory mouse. Indeed, experiments designed to elucidate this theory demonstrated that the activity of the enzyme in the field-trapped desert rodents was about one-ninth of that observed 


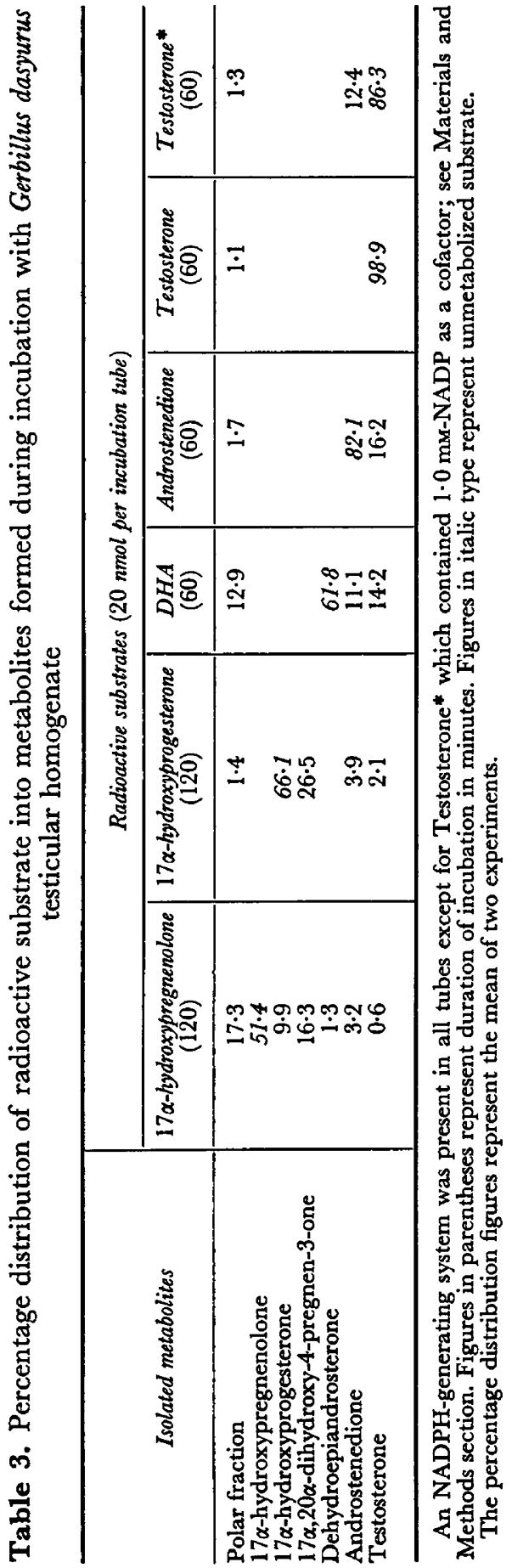


in the ordinary laboratory mouse, a quarter of that found in the hamster and similar to that of the rat. Moreover, the effect of heat-acclimatization on the activity of the enzyme was particularly noticeable in the mouse, where it decreased by $28.3 \%$ after acclimatization (Text-fig. 1 ). Conversely, the effect of acclimatization on the hamster and rat was less evident and the decline in the enzyme activity compared to that of controls was only 8.7 and $8.3 \%$, respectively.

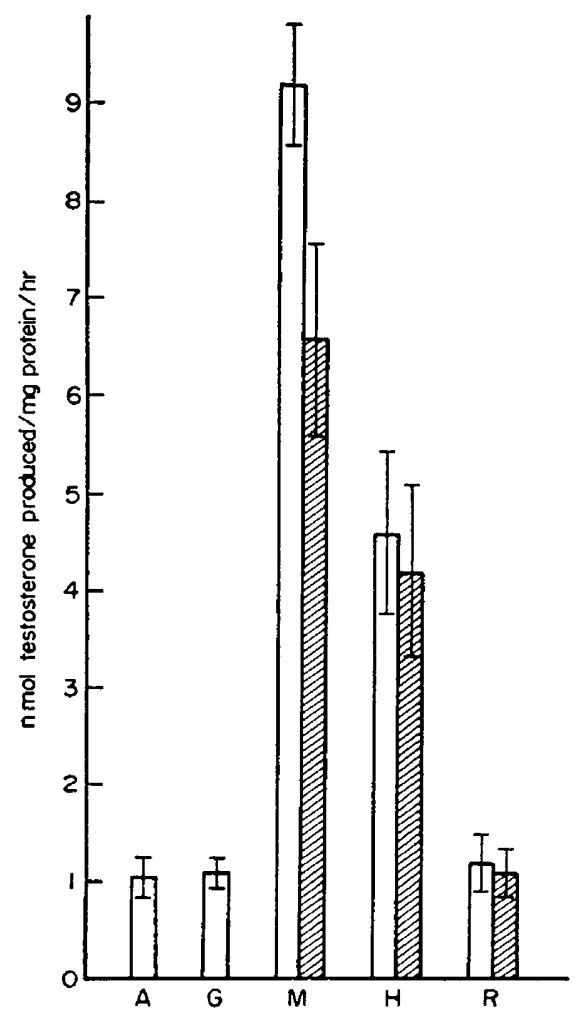

Text-Fig. 1. Comparative activity of $17 \beta$-hydroxysteroid oxidoreductase in testis of field-trapped Acomys cahirinus (A) and Gerbillus dasyurus (G), and control (open columns) and heat-acclimatized (hatched columns) mouse $(\mathbf{M})$, hamster $(H)$ and rat $(R)$.

Which is the predominant route for testosterone biosynthesis in desert rodents?

The data presented so far indicated that testosterone is synthesized by both the 5-ene and 4-ene routes, but that the rôle of the latter might be more significant under our experimental conditions. Experiments were carried out to determine the extent to which 5 -ene- $3 \beta$-hydroxysteroids and the corresponding 4-en-3-oxosteroids were converted to their 4-en-3-oxo metabolites and ultimately to testosterone. In these experiments, equimolar amounts $(20 \mathrm{nmol})$ of double-labelled substrate pairs, (a) $\left[7-{ }^{3} \mathrm{H}\right] 17 \alpha$-hydroxypregnenolone and [4$\left.{ }^{24} \mathrm{C}\right] 17 \alpha$-hydroxyprogesterone, and (b) $\left[7-{ }^{3} \mathrm{H}\right] \mathrm{DHA}$ and $\left[4-{ }^{14} \mathrm{C}\right]$ androstenedione were incubated, in the presence of NADPH- and NADH-generating 
systems, with testicular homogenates of the desert rodents. The metabolism of 5 -ene steroids to 4-ene requires at least two steps involving two enzymes: $3 \beta$-hydroxysteroid dehydrogenase and 5 -ene-ketosteroid isomerase, but these steps were not studied individually. The results of these studies (Table 4) clearly indicate that in both the desert rodent species, testosterone is synthesized preferentially by the 4-ene pathway. Moreover, the crossover reaction between $17 \alpha$-hydroxypregnenolone and $17 \alpha$-hydroxyprogesterone favours the formation

Table 4. Molar ratios* of metabolites derived from 4-ene precursors to those derived from 5-ene precursors incubated with testicular homogenate of Acomys cahirinus and Gerbillus dasyurus

\begin{tabular}{|c|c|c|c|c|}
\hline \multirow{3}{*}{ Metabolites } & \multicolumn{4}{|c|}{ Substrate pair } \\
\hline & \multicolumn{2}{|c|}{$\begin{array}{c}{\left[7-^{3} H\right] 17 \alpha-h y d r o x y p r e g n e n o l o n e} \\
\text { and }\left[4-{ }^{14} C\right] 17 \alpha-h y d r o x y- \\
\text { progesterone }\end{array}$} & \multicolumn{2}{|c|}{$\begin{array}{l}{\left[7-{ }^{3} \mathrm{H}\right] \text { dehydroepiandrosterone }} \\
\text { and }\left[4-^{-14} \mathrm{C}\right] \text { androstenedione }\end{array}$} \\
\hline & $A$ & $G$ & $A$ & $G$ \\
\hline $\begin{array}{l}\text { 17 } \alpha \text {-hydroxypregnenolone } \\
17 \alpha \text {-hydroxyprogesterone } \\
17 \alpha, 20 \alpha \text {-dihydroxy-4-pregnen-3-one } \\
\text { Dehydroepiandrosterone } \\
\text { Androstene- } 3 \beta, 17 \beta \text {-diol } \\
\text { Androstenedione } \\
\text { Testosterone }\end{array}$ & $\begin{array}{c}0 \\
56 \cdot 6 \\
24 \cdot 8 \\
0 \\
0 \\
29 \cdot 4 \\
127 \cdot 0\end{array}$ & $\begin{array}{c}0 \\
12 \cdot 5 \\
9 \cdot 6 \\
0 \\
0 \\
2 \cdot 5 \\
15 \cdot 0\end{array}$ & $\begin{array}{c}0 \\
0 \\
12 \cdot 1 \\
43 \cdot 4\end{array}$ & $\begin{array}{c}0 \\
0 \\
11.4 \\
3.6\end{array}$ \\
\hline
\end{tabular}

A, data for Acomys cahirinus; G, data for Gerbillus dasyurus. (Part of these data already published; Bedrak, Samoiloff \& Finkelstein, 1971.)

* The ratios were determined after recrystallization to constant specific activity. All values are means of duplicate determinations.

of the 4-ene steroid. Similarly, the crossover reaction of DHA and androstenedione favours the formation of the 4-ene steroid. Under our experimental conditions, reaction steps with $3 \beta$-hydroxysteroid oxidoreductase and 5-en-oxosteroid isomerase participating are irreversible.

\section{DISCUSSION}

The data presented here demonstrated that testicular homogenates of $G$. dasyurus and $A$. cahirinus contain enzymes which metabolize steroids by both the 5-ene and 4-ene pathways as do those of ordinary laboratory mice (Ellis \& Berliner, 1965) but that testosterone is preferentially synthesized by way of the latter route. However, comparison of testosterone biosynthesis in vitro in the desert rodents and laboratory mice shows two fundamental differences, as, for example, in Step C and Step E in the generalized schemes for androgen biosynthesis (Text-fig. 2). The activity of the enzyme participating in the reaction of Step C, $20 \alpha$-hydroxysteroid oxidoreductase, is much greater in desert rodents than in laboratory mice. This enzyme, present in the supernatant, has been shown to inhibit the synthesis of testicular androgens both by competing for the common substrate $17 \alpha$-hydroxyprogesterone, and by forming $17 \alpha, 20 \alpha$-dihydroxy-4-pregnen-3-one, a competitive inhibitor of the 4-ene-17,20-lyase which 
converts $17 \alpha$-hydroxyprogesterone to androstenedione (Inano, Nakano, Shikita $\&$ Tamaoki, 1967). A relatively high activity of the $20 \alpha$-hydroxysteroid oxidoreductase has been observed in the testes of rats acclimatized to a hot environment (Bedrak, Samoiloff, Sod-Moriah \& Goldberg, 1971). These findings, together with the high intrascrotal temperature observed in heat-acclimatized rats $\left(1.3^{\circ} \mathrm{C}\right.$ higher than in control rats; Sod-Moriah, Bedrak \& Goldberg, 1972), compare well with the work of Fevold \& Eik-Nes (1962) who found high levels

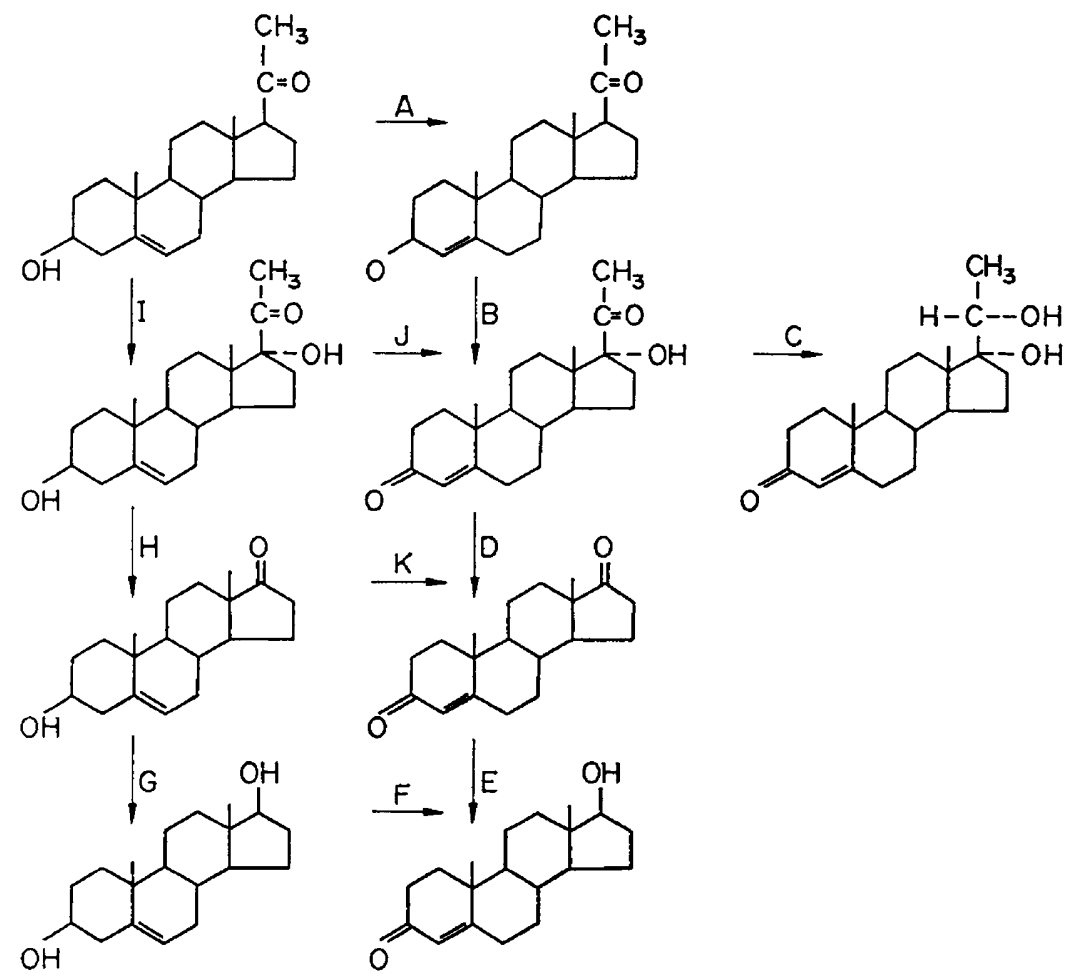

TexT-FIG. 2. Generalized schemes for androgen biosynthesis. Arrowed capitals indicate the action of one or more enzyme systems.

of this enzyme in sparrow testes (which are at a higher temperature than those of control rats). Since this enzyme may be involved as a possible regulatory mechanism of testicular steroidogenesis (Inano et al., 1967), its high activity demonstrated in $G$. dasyurus and $A$. cahirinus testicular homogenates could account, in part, for the relatively low rate of testosterone synthesis from C-21 precursors. Moreover, although the activities of the enzymes were similar in $A$. cahirinus, in G. dasyurus the activity of 17,20-lyase (Step D) is several-fold greater than the activity of $20 \alpha$-hydroxysteroid reductase. Step $E$ involves the action of $17 \beta$-hydroxysteroid oxidoreductase, and the data presented indicate that the activity of this enzyme is about the same in both desert rodent species, but is much lower than that observed in laboratory mice. It has been shown that acclimatization of laboratory mice to a hot environment results in a significant 
decrease in the activity of $17 \beta$-hydroxysteroid oxidoreductase. This suggests, although remotely, that the lower enzyme activity observed in these desert animals may be associated with the genetic composition of the species which, by natural selection, have become inured to environmental extremes. Thus, the combined effects of the increased activity of $20 \alpha$-hydroxysteroid oxidoreductase which decreases the substrate level (17 $\alpha$-hydroxyprogesterone) available for the production of androstenedione, and the low activity of $17 \beta$-hydroxysteroid oxidoreductase which converts androstenedione to testosterone, result in an overall decrease in the testosterone produced in vitro.

In addition, the activity of both 5 -ene- $3 \beta$-hydroxysteroid oxidoreductase and 5 -ene-ketosteroid isomerase, metabolizing $17 \alpha$-hydroxypregnenolone to $17 \alpha$ hydroxyprogesterone (Step J), is as great as that of the corresponding enzymes which transform DHA to androstenedione (Step K). The relative activity of the corresponding enzymes participating in Step A and also in Steps B and I is difficult to interpret from these results. Moreover, species differences exist with respect to the activity of 17,20-lyase for the 5-ene pathway (Step H), and for the 4-ene route (Step D). Similarly, species differences were observed with the enzymes converting DHA to testosterone (Steps G and F).

The use of in-vitro experiments for interpreting in-vivo conditions has limited validity, particularly if parameters such as the endogenous levels of steroids and endogenous cofactor concentrations are not taken into account (Matsumoto \& SamueIs, 1969). Some of these parameters could affect the accurate estimation of the extent of the activities and may result in mistaken evaluation of the data. Although the endogenous levels of steroids were not estimated in these experiments, the authors feel that the dilution of the radioactive substrate by the endogenous steroids was not a major factor in changing the enzymatic reaction rate. If it can be assumed that the concentration of steroids in testicular tissue of desert rodents is not very different from that found in other mammals, the premise would be valid. Then, according to van der Molen (1970), $50 \mathrm{mg}$ of tissue (the quantity of testicular tissue present in each incubation tube of the experiments reported here) should contain between 0.005 and $0.034 \mathrm{nmol}$ of testosterone and $0.003 \mathrm{nmol}$ of androstenedione. Since the quantity of substrate used in the experiments was $20 \mathrm{nmol}$, the maximum levels of endogenous testosterone and androstenedione would approximate $0.17 \%$ and $0.015 \%$, respectively, of the substrate added. Dilution by the endogenous steroids, if present at the concentration given, could not therefore have affected the results significantly. Although present experiments favour the interpretation that testosterone is preferentially synthesized through the 4-ene pathway, additional data are needed from intact animals before a definitive conclusion can be drawn.

\section{ACKNOWLEDGMENTS}

The authors are grateful to Dr O. Fürst, F. Hoffman-La Roche \& Co., Basle, Switzerland, for the supply of authentic $17 \alpha, 20 \alpha$-dihydroxy-4-pregnen-3-one and to Professor G. M. H. Waites, Department of Physiology and Biochemistry, Reading University, England, for helpful suggestions in revising the manuscript. They also wish to thank Mrs Cynthia Bellon for skilled editorial assistance. 


\section{REFERENGES}

Bedrak, E., SAmoiloff, V. \& Finkelstein, Z. (1971) Testosterone biosynthesis in the desert mouseAcomys cahirinus. F. Endocr. 51, 7.

Bedrak, E., SAmolloff, V., Sod-Moriah, U. A. \& Goldberg, S. (1971) Synthesis of androgens in vitro by testes of rats acclimatized to a hot environment. F. Endocr, 51, 489.

Bedrak, E. \& SAmuels, L. T. (1969) Steroid biosynthesis by the equine testis. Endocrinology, 85, 1186.

Dominguez, O. V., Seely, J. R. \& Gorski, J. (1963) Studies of the acetylation of steroids using 1-carbon-14-acetic anhydride. Analyt. Chem. 35, 1243.

EIK-Nes, K. B. (1970) Synthesis and secretion of androstenedione and testosterone. In: The Androgens of the Testis, p. 1. Ed. K. B. Eik-Nes. Marcel Dekker, New York.

Ellerman, J. R. \& Morrison-Scott, T. G. S. (1966) Checklist of palaerarctic and Indian mammals 1758 to 1946, pp. 615, 633. Trustees of the British Museum (Natural History), London.

Ellis, L. G. \& BERLINER, D. L. (1965) Sequential biotransformation of 5-pregnenolone-7 $\alpha-{ }^{3} \mathrm{H}$ and progesterone $-4-{ }^{14} \mathrm{C}$ into androgens by mouse testes. Endocrinology, 76, 591.

Fevold, H. R. \& Erk-Nes, K. B. (1962) Progesterone metabolism by testicular tissue of the English sparrow (Passer domesticus) during the annual reproductive cycle. Gen. $\mathscr{E}$ compar. Endocr. 2, 506.

Inano, H., Nakano, H., Shikita, M. \& TAMaoki, B. (1967) The influence of various factors upon testicular enzymes related to steroidogenesis. Biochim. biophys. Acta, 137, 540 .

Lowry, O., Rosebrough, N. J., Farr, A. L. \& Randall, R. J. (1951) Protein measurement with Folin phenol reagent. F. biol. Chem. 193, 265.

Matsumoto, K. \& Samuels, L. T. (1969) Influence of steroid distribution between microsomes and soluble fraction on steroid metabolism by microsomal enzymes. Endocrinology, 85, 402.

Shachak, M. \& McPheE, E. (1971) Microclimatic conditions as a factor in spatial separation of two desert rodents (Acomys cahirinus and Gerbillus dasyurus). Int. J. Biomet. 15, 91.

SoD-Moriar, U. A., BEDRAK, E. \& GoldBerg, G. M. (1972) Fertility and histological changes in testes of male rats maintained at $35^{\circ}$ for 20 weeks. In: 9th International Congress of the International Academy of Pathology, Jerusalem.

VAN DER MOLEN, H. J. (1970) Estimation of androstenedione and testosterone by physical methods. In: The Androgens of the Testis, p. 145. Ed. K. B. Eik-Nes. Marcel Dekker, New York.

Zafraroni, A. (1953) Micromethods for the analysis of androcortical steroids. Recent Prog. Horm. Res. 8, 51. 